\title{
Tertampiknya Injil-injil Gnostik
}

\author{
Mika Sulistiono \\ Sekolah Tinggi Alkitab Tiranus \\ Email: sulistionomika@gmail.com
}

\begin{abstract}
Until now, challenges on the validity of the Bible based on the use of the Gnostic Gospels are still rampant, especially by anti-orthodox Christians and liberals. For this reason, this study attempts to answer the question of how the historical description of the Gnostic Gospels was dismissed in the century of its appearance, so that it did not enter the New Testament canon. Through a qualitative-descriptive research method, it was found that the answer to the rejection of the Gnostic Gospels as part of the canon was due to: 1). there is a significant time gap between the appearance of the Gnostic Gospels and the canonical ones, 2). its distribution was secret, and was not common among the early Christian congregations. 3). his teachings that contradict the teachings of the canonical gospels about the life of the Lord Jesus and the way of human salvation, 4). several important figures of the second to third centuries such as Irenaeus, Tertullian, Clemens, Origens, and Esuibius firmly rejected the Gnostic Gospels to enter the canon. The result of this research certainly confirms the Christian belief in the acknowledgment of the validity of the New Testament canon.
\end{abstract}

Keywords: canonical gospel, rejected, Gnostic gospel

\begin{abstract}
Abstrak
Hingga kini serangan terhadap kesahihan Alkitab berdasarkan pemanfaatan Injil-injil Gnostik masih marak, terutama dilakukan oleh pihak anti-ortodoksi dan liberalisme. Atas alasan tersebut, penelitian ini hendak menjawab pertanyaan masalah tentang bagaimana gambaran historis tertampiknya Injil-injil Gnostik pada abad permunculannya, sehingga tidak masuk ke dalam kanon Perjanian Baru. Melalui metode riset kualitatif-deskriptif, ditemukan jawaban bahwa penampikan Inji-injil Gnostik sebagai bagian kanon oleh karena: 1). adanya gap waktu yang signifikan antara munculnya Injil-injil Gnostik dengan yang kanonik, 2). penyebarannya yang bersifat rahasia, dan tidak umum di antara jemaat Kristen purba. 3). ajaranajarannya yang kontradiksi dengan ajaran Injil-injil kanonik tentang kehidupan Tuhan Yesus dan jalan keselamatan manusia, 4). beberapa tokoh penting abad kedua hingga abad ketiga seperti Irenaeus, Tertullian, Clemens, Origens, dan Esuibius menolak tegas kelayakan Injil-injil Gnostik untuk masuk kanon. Hasil penelitian ini tentunya mengkokohkan keyakinan Kristen atas pengakuan kesahihan kanon Perjanjian Baru.
\end{abstract}

Kata Kunci: Injil kanonik, tertampik, Injil Gnostik. 


\section{Pendahuluan}

Perkembangan ketertarikan "ahli-ahli Perjanjian Baru tertentu" pada ajaranajaran Gnostik patut menjadi perhatian serius bagi orang-orang Kristen yang setia pada Alkitab. Robert P. George melalui artikelnya yang termuat dalam A Montly Journal of Religion and Public mengungkapkan bahwa ajaran-ajaran Gnostik menjadi ajaran yang bisa mengkompromikan suatu variasi dari berbagai ideologi leburan asketik yang sangat diminati sekarang ini, serta menjadi lawan bagi konsepsi "human being."2 Ajaran ini mulai cukup digemari di dunia barat, oleh karena minat-minat pencarian kehidupan baru dengan mencoba menyimak ajaran-ajaran semacam gnostikisme yang bersentuhan dengan astrologi, horoskop, dan asketikisme. ${ }^{3} \quad$ Kurang dari sepuluh tahun belakangan ini, cukup marak kekristenan berhaluan liberalis yang tertarik dengan tulisan Elaine Pagels dari Princeton University yang berjudul The Gnostic Gospels. Elaine Pegals dalam tulisan menunjukkan keseriusan untuk mengganti ajaran-ajaran orthodoks dengan Injil-injil Gnostik. George Robert setuju dengan pemikiran Pegals bahwa konsep "ajaran tradisional gereja purba hanya bermakna internal terbatas bagi tradisi apostolik saja," tanpa mau mengakomodir dinamika perkembangan ajaran Gnostik yang ikut mewarnai zamannya. ${ }^{4}$ Menurut Jonathan Cahana yang juga setuju dengan pemikirannya Alaine Pagels merasa keberatan dengan penilaian ahli-ahli Perjanjian Baru orthodoks yang melihat Injil-injil Gnostik hanya dari tradisi kacamata apostolik dan gereja perdana. ${ }^{5}$ Nampaknya, tidak sedikit "ahli Perjanjian Baru" yang concern dengan Injil-injil Gnostik memandang bahwa, orthodoksi bukanlah pandangan yang sudah eksis sampai abad awal Kekristenan. ${ }^{6}$ Keyakinan orthodoksi dipandang sebagai gangguan ajaran-ajaran Gnostik yang merupakan bentuk-bentuk dominan pada awal sampai abad kedua.

Tentunya apa yang menjadi pandangan sekelompok "ahli-ahli Perjanjian Baru" yang adalah pendukung usaha perelevansian Injil-injil Gnostik di atas merupakan suatu tatangan serius yang patut dijawab oleh orang-orang Krsiten yang setia pada pandangan orthodoks. Sebagaimana pernyataan Andy Olsen, bahwa gereja masih memerangi ajaran-ajaran Gnostik hari-hari ini. ${ }^{7} \quad$ Pandangan mereka tentunya menunjukan gap yang tegas dengan keyakinan orthodoks perihal kitab-kitab terkanon. Berdasarkan latar belakang munculnya usaha-usaha untuk menggoyang kembali kesahihan kitab-kitab Perjanjian Baru oleh pemahaman liberalisme dengan memanfaatkan Injil-injil Gnostik, maka sangat penting untuk melakukan penelitian tentang bagaimana sebenarnya

\footnotetext{
${ }^{1}$ Ahli-ahli Perjanjian Baru berhaluan liberal.

2 Robert P George, "Gnostic Liberalisme", First Thing: A Montly Journal of Religion and Public (Desember 2016): 34 .

${ }^{3}$ Kees De Jong, "The Resurection of the Gnostis: Gospel of Judas, Da Vinci Code A Historical Review of Religion", Gema: Jurnal Teologi (2007): 7.

${ }^{4}$ George, "Gnostic Liberalisme," First Thing: A Montly Journal of Religion and Public, 34.

${ }^{5}$ Dipandang perlu memahami ajaran-ajaran Gnostik dan perspektif perkembangan pemajuan penggenapan Firman Tuhan. Jonathan Cahana "None of Them Knew Me of My Brothers: Gnostic Antitraditionalisme and Gnosticism as Cultural Phenomenon," Journal of Religion, Volume 94 (2013): 55.

6 J. Tiche William "The Neo Gnostic: Alternatif Christianity of Elaine Pagels", Touchstone: A Journal of Mere Christianity," Volume 24, Issue 6, November/ December (2013): 34.

7 Andy Olsen "Go West Young Scholar," Journal: Christian Today, Volume 63, Issue 7 (September 2019): 7
} 
gambaran historis penolakan Injil-injil Gnostik pada masa permunculannya setelah periode masa-masa penulisan Injil-injil kanonik Perjanjian Baru. Melalui penelitian terhadap beberapa buku dan jurnal yang membahas sejarah respon terhadap Injil-injil Gnostik, maka jawaban atas permasalahan tersebut bisa ditemukan.

Topik di atas sangat perlu dibahas demi memberikan counter terhadap usahausaha merongrong keyakinan Kristen atas Alkitabnya, yang dengan serius memanfaatkan secara buta dari penemuan Inji-injil Gnostik. Secara praktis dan internal, penulis bermaksud hendak meneguhkan keyakinan orang Kristen pada otoritas Firman Tuhan, yakni Alkitab - secara lebih khusus Perjanjian Baru. Hal mana dari waktu ke waktu kekristenan terus bertempur menghadapi kepalsuan dan pemalsuan atas kebenaran Firman Tuhan. Apalagi dengan maraknya penelahan kembali Injil-injil Gnostik belakangan, yang memungkin para anti-kristen dengan mudah menemukannya melalui situs-situs internet, media literatur, dan forum-forum diskusi lintas kepercayaan.

Penelitian yang berfokus pada pandangan-pandangan atas Injil-injil Gnostik ini bukan bermaksud menemukan gambaran-gambaran detail dari eksistensi per individu kitab-kitabnya dan mendiskusikan secara mendalam ajarannya. Fokus dari penelitian ini lebih kepada usaha menemukan alasan-alasan "dasar" (baca: awal, fundamental, dan menentukan) mengapa keberadaannya tertampik untuk menjadi bagain dari Alkitab. Penelitian ini secara khusus memahami pergulatan dan kekokohan eksistensi Alkitab itu sendiri dan tokoh-tokoh yang setia pada kitab-kitab terkanon pada abad kedua hingga ketiga dalam sikapnya menghadapi munculnya ajaran-ajaran Kristen Gnostik. Secara lebih tegas, penelitian ini mengarah kepada usaha penggambaran keterwujudsatukan (baca: terwujud hingga menjadi satu kanon) dari kitab-kitab Perjanjian Baru itu sendiri sebagai alasan-alasan dasar penampikan Injil-injil Gnostik pada abad kedua hingga ketiga, serta bagaimana sikap beberapa tokoh penting rentang waktu tersebut mengkonfirmasikannya.

\section{Metode}

Penelitian ini ditempuh dengan menggunakan pendekatan kualitatif-deskriptif. Sebagaimana penjelasan Sugiono, bahwa yang termasuk penelitian semacam ini adalah juga penelitian terhadap dokumen-dokumen atau literatur-literatur yang disebut sebagai studi literatur. Peneliti menjadi instrumen dalam membaca, menganalisa, menafsirkan, dan menyimpulkan temuan-temuannya yang mengarah pada jawaban atas permasalahan risetnya. Ini semacam studi induktif atas data-data tertulis. ${ }^{8}$ Hal yang sama diungkapkan oleh Subana dan Sudrajat, bahwa penelitian kualitatif-deskriptif merupakan penelitian yang berusaha menuturkan dan menafsirkan data, fakta, historis dari suatu pandangan secara deskriptif. ${ }^{9}$ Penggunaan metode penelitian tipe ini bertujuan untuk mendapatkan deskripsi atas fokus persoalan Injil-injil Gnostik yang bersumber pada literatur-literatur. Literatur-literatur dan jurnal-jurnal yang menjadi sumber data adalah literatur-literatur dan jurnal-jurnal yang membahas tentang historika permunculan Injil-injil Gnostik di tengah-tengah perkembangan awal kekristenan,

\footnotetext{
${ }^{8}$ Sugiono, Metode Penelitian (Kuantitatif, Kualitatif, dan R\&D) (Bandung: Penerbit Alfa Beta, 2017), 15.

${ }^{9}$ M. Subana dan Sudrajat, Dasar-dasar Penelitian Ilmiah. (Bandung: Penerbit Pustaka Setia, 2005), 85.
} 
tertolaknya kumpulan Injil-injil palsu sebagai bagian dari kitab-kitab Perjanjian Baru dan pandangan-pandangan beberapa tokoh kunci yang menampik eksistensi injil-injil tersebut sebagai yang setara otoritasnya dengan kitab-kitab Perjanjian Baru.

Sumber-sumber literatur dan jurnal terhimpun untuk kepentingan riset ini antara: 1). Buku-buku dan jurnal-jurnal yang memberikan gambaran tentang Injil-injil Gnostik, antara lain seperti: The Nag Hammadi Library karya Robinson, James M, The Gnostic Gospels karya dan Why Religion? (A Personal Story) keduanya karya Elaine Pagels, juga buku The Gnostic Bible karya Willis Barnstone dan Marvin Meyer. Sedangkan data-data dari topik Injil-injil Gnostik yang muncul dalam beberapa jurnal antara lain: Gnostic Liberalism oleh Robert P George dalam A Montly Journal of Religion, None of The Knew Me of My Brothers: Gnostic Antitraditionalisme and Gnosticism as Cultural Phenomenon oleh Jonathan Cahana dalam Jornal Of Religion, Gnostic Evangelist oleh William J. Tiche dalam A Journal of Mere Christianity, Beyond The Gnostic Gospels: Studies Building on the Work of Elaine Pagels dalam The Journal of Ecclesiastical History, serta artikel berjudul Political Theology: Gnostic karya Miguel Vatter dalam Journal of Religion. 2) Untuk buku-buku dan topik terkait dari jurnal-jurnal yang memberikan pandangan-pandangan menentang atau menampik eksistensi Injil-injil antara lain: buku berjudul Canon and Biblical Interpretation karya Craig Bartholomew, Scott Hahn, dan Robin Party, The Canon of Scripture karya FF Bruce, Siapa yang Membuat Akitab? (Penyelesaian dan Kewibawaan Perjanjian Lama dan Perjanjian Baru) karya Bruggen, Jakob Van Bruggen, Scripture and Truth karya D.A Carson dan John D. Woodbridge, Runtut Pijar (Sejarah Pemikiran Kristiani) karya Tony Lane, juga buku The Origin of The Bible karya Philip Wesley Comfort.

Selanjutnya artikel dalam jurnal-jurnal yang menjadi sumber-sumber informasi penolakan tentang Injil-injil Gnostik antara lain: artikel dengan judul What is A Gnostic Gospel? Karya Perkins Pheme dalam Journal Chatolic Biblical Quaterly, Go West Young Scholar (Sebuah Komentar) oleh Andy Olsan dalam Christianity Today, The Secret Book of John The Gnostic Gospel karya Martin McNamara dalam Heythrop Journal, Pengaruh Ajaran Gnostik dalam Kekristenan tulisan Damanik, Jon Mister R dalam Jurnal Teologi - Logon Zoes, Perbandingan Ajaran Gnostikisme dengan Ajaran Reformed Mengenai Pengetahuan Akan Allah karya Lukman Purwanti dalam Jurnal Teologi dan Pendidikan Agama Kristen, Tantangan Gnostik bagi Hidup Beriman Masa Kini karya Matheus Purwatma dalam Jurnal Orientasi Baru, serta artikel Tanggapan Terhadap Gnostikisme dan Injil Tomas karya Roby Setiawan dalam Jurnal Teologi dan Pendidikan Agama Kristen.

Berdasarkan sumber tulisan-tulisan tersebut di atas, peneliti melakukan analisa dan interpretasi, kemudian menarik kesimpulan-kesimpulan tentang bagaimana sebenarnya respon atas Injil-injil Gnostik yang beredar waktu itu. Dari hasil penelitian ini, diharap akan memperkaya kasanah keilmuan teologi - terutama bidang bibliologi dan memberikan peneguhan praktis bagi orang-orang percaya yang sehari-hari bisa secara langsung berhadap-hadapan dengan serangan terhadap eksistensi Alkitab. 


\section{Hasil Pembahasan dan Kesimpulan}

Berdasarkan pendalaman terhadap literatur-literatur bagi penelitian tentang pokok munculnya Injil-injil Gnostik, maka berikut kesimpulan berturut-turut tentang masa muncul dan ajaran-ajaran dari Injil-injil Gnostik, serta alasan-alasan mendasar bagi tertolaknya injil-injil Gnostik untuk menjadi bagian dari kanon Perjanjian Baru.

Masa Muncul dan Sekilas Ajaran dari Injil-injil Gnostik

Kurang lebih tujuh puluh tahun yang lalu dunia arkeologi Alkitab - terutama bidang penelitian naskah-naskah kuno - digairahkan oleh ditemukannya traktat-traktat Gnostik pada situs Nag Hamadi di Mesir. ${ }^{10}$ Tepatnya pada tahun 1945 di area tepian Sungai Nil, Mesir Utara, sekelompok petani menemukan guci-guci besar yang berisi kurang lebih 52 traktat-traktat Injil rahasia. ${ }^{11}$ Semuanya merupakan traktat-traktat dalam bentuk codex yang berbahasa Yunani dan Coptik. James M. Robinson mengidentifikasikan kumpulan traktat-traktat tersebut sebagai kelompok Injil-injil Gnostik karena judul-judul yang tertulis di dalamnya. Nampaknya itu sebuah koleksi besar dari perpustakaan teks relijius. ${ }^{12}$ Penamaan dan pengklasifikasian dari traktattraktat tersebut, terkait dengan keyakinan kelompok atau kaum Kristen Gnostik yang merupakan sempalan penganut Kristen. Mereka sering disebut sebagai pseudo-Kristen. Yakni, komunitas Kristen yang mengaku sebagai orang-orang Kristen, namun kitabnya berorientasi pada Injil-injil Gnostik. ${ }^{13}$

Injil-injil Gnostik yang teridentifikasi seolah-olah tulisan dari para rasul dengan penamaan yang populer, antara lain; Injil Petrus, Injil Thomas, Injil Yudas, Injil Nazorean, Injil Hibrani, Injil Filipus, Injil Mesir, Injil Maria, Injil Nikodemus, Injil Kebenaran, Injil Ebionit, Injil Basilides, dan yang lainnya, benar-benar meramaikan studi historis tentang naskah-naskah relijius sekitar masa terbentuknya Perjanjian Baru. Penyebutan Injil-injil Gnostik itu sendiri sesuai dengan penjudulan pada traktattraktatnya. $^{14}$ Rupanya para penulis asli telah menyamarkan tulisannya dengan menggunakan nama salah satu rasul dan bukan nama sendiri. Mereka berpura-pura menggunakan otoritas rasul-rasul. ${ }^{15}$ Ini seperti yang diungkapkan Paulus bahwa ada orang-orang yang menganggap dirinya seolah-olah mendapat ilham roh atau mengatasnamakan rasul-rasul kemudian menurunkan berita-berita yang menyesatkan (2 Tesalonika 2:2).

Dari antara sekian banyak Injil Gnostik, yang paling populer serta menjadi bahan diskusi para teolog dan ahli Perjanjian Baru adalah Injil Thomas, Injil Maria, dan Injil Yudas. Penemuan dan penelaahan atas Injil-injil Gnostik mengusik keyakinan dan

\footnotetext{
${ }^{10}$ Craig Batholomew, Scott Hahn, Robin Party, and Seitz, Christoper, Canon and Biblical Interpretation (Volume 7) (Grand Rapids: Redeemer University College, 2006), 120.

${ }^{11}$ James M. Robinson, The Nag Hammadi Library (San Fransisco: Harper \& Row Publishers. 1981), 52. 12 Ibid, 1.

13 J. ED. Komoszewski, Sawyer, M. James., dan Wallace, Daniel B, Reinventing Jesus: Bagaimana Para Pemikir Skeptis Keliru Memahami Yesus dan Menyesatkan Budaya Populer (Jakarta: Perkantas - Divisi Literatur, 2011), 129.

${ }^{14}$ Philip Wesley Comfort, The Origin of The Bible, (Illinois: Tyndale House Publishers. 1998), 90-92.

15 Norman L. Geisler dan Ron Brooks, Ketika Alkitab Dipertanyakan (Yogyakarta: Andi Offset, 2006), 183.
} 
pandangan para teolog liberal tentang eksistensi Perjanjian Baru yang dipegang selama ini. Malahan, beberapa waktu yang lalu Elaine Pagels - seorang profesor agama-agama di Universitas Princenton - mengkampanyekan usaha-usaha untuk menggantikan kekristenan tradisonal menjadi kekristenan yang bercorak dan berorientasi pada ajaranajaran Gnostisisme. Walau beliau tidak bermaksud menghapuskan kekristenan dengan mengggantikannya menjadi agama Kristen Gnostik, namun dia memiliki keinginan untuk mengubah dasar-dasar kekristenan orthodoks yang sudah teruji ribuan tahun. Melalui tulisannya berjudul The Gnostic Gospels, beliau telah mencoba merekonstruksi keyakinan kekristenan konservatif-orthodoks dalam ajaran-ajarannya. ${ }^{16}$ Tantangan semacam ini merupakan hal yang biasa terjadi dan menjadi pergumulan kaum Injili untuk menanggapinya.

Berdasarkan riset dan kesimpulan para ahli Perjanjian Baru, diyakini bahwa naskah Injil-injil Gnostik ditulis di sekitaran abad kedua, jauh setelah seluruh kitab Perjanjian Baru ditulis, terutama setelah keempat Injil yang kanonik terwujud, bahkan tersatukan. Masa munculnya Kristen Gnostik dan Injil-injil Gnostiknya adalah masa dimana kekristenan mengalami perkembangan yang signifikan, yang kemudian hari mampu membawa pengaruh besar pada kekaisaran Romawi. Faktanya memang mulai abad kedua kekristenan tidak lagi dipandang sebagai bidat Yahudi, namun menjadi agama yang berpotensi menjadi agama universal. ${ }^{17}$

Situasi yang kompleks antara perwujudan komunikas Kristen, semangat penyambutan dan pengandalan otoritas pada Perjanjian Baru sebagai dasar ajaran bagibagi orang-orang Kristen awal, munculnya ajaran-ajaran palsu, serta tertulisnya banyak Injil Gnostik menjadikan abad kedua memasuki abad ketiga, sebagai situasi yang sulit. Hal ini berkenaan dengan tantangan atas ajaran-ajaran para rasul yang harus dipegang sebagai kitab sucinya, atau paling tidak sebagai tulisan-tulisan otoritatif, serta perjuangan, baik secara eksternal menghadapi Yudaisme dan pemerintahan Romawi maupun secara internal menghadapi bidat-bidat. Sebagaimana pernyataan Andy Olsen dalam komentarnya terhadap gerakan Injil-injil Gnostik:

Kekristenan memiliki banyak celah dalam perlengkapan doktrinalnya di masa-masa awal ketika kredo-kredonya masih kokoh dan sementara penganiayaan yang disponsori oleh negara sedang menopangnya di semua lini kehidupan. Gangguan naas dari bidat-bidat Gnostik khususnya, dengan banyak cara kreatif telah berusaha memisahkan fisik dari spiritual akan menyebabkan kerusakan ratusan tahun. ${ }^{18}$

Craig Bartholomew dan Anthony Thiselton menuturkan bahwa kelompok Gnostik menjadi suatu komunitas yang telah berusaha menafsirkan Alkitab dengan cara yang sangat berbeda dari proto-orthodox sebagai the rule of faith. Sikap dan usahanya tentu

\footnotetext{
${ }^{16}$ Pate C. Marvin dan Sheryl L, Disalibkan oleh Media (Yogyakarta: Andi Offset, 2007), 31.

${ }^{17}$ Tony Lane, Runtut Pijar (Sejarah Pemikiran Kristiani) (Jakarta: BPK Gunung Mulia, 1990), 3.

${ }^{18}$ Andy Olsen, "Go West Young Scholar," Journal: Christian Today, Volume 63, Issue 7 (September 2019): 7.
} 
menjadi persoalan internal yang tidak bisa dipandang enteng. ${ }^{19}$ Salah satu tokoh tersohor pendukung revitalisasi Injil-injil Gnostik yang dikutip oleh J Tiche William, mengatakan: 'Kanon Perjanjian Baru tidak memiliki prioritas apapun baik dalam waktu penyusunan, keaslian isi, atau otoritas untuk kepercayaan atas yang lain, non-kanonik dokumen-dokumen." 20 Tak pelak lagi gerakan Kristen Gnostik mengganggu usahausaha pendalaman ajaran-ajaran Kristen atau dogmata (baca: ajaran-ajaran praktis) secara internal pada masa itu. ${ }^{21}$

Berbeda dengan tulisan-tulisan apokrif, Injil-injil Gnostik ternyata sangat kental dipengaruhi oleh ajaran-ajaran Gnostik yang populer pada abad kedua dan ketiga. ${ }^{22}$ Sekolah-sekolah Gnostik muncul sebagai pembawa filsafat Gnostik yang adalah campuran mistik dan neoplatonisme yang sudah ada jauh sebelumnya. ${ }^{23}$ Mesir telah menjadi kawasan paling suburnya bagi ajaran Gnostik. ${ }^{24}$ Kepopuleran ajaran Gnostik sungguh nyata oleh karena pengaruhnya pada abad pertama dan kedua. Paham ini sebenarnya tidak saja telah mempengaruhi kekristenan sehingga muncul kekristenan Gnostik, tetapi juga telah mengkhamiri berbagai pandangan di luar kekristenan. Pada tahun $200 \mathrm{M}$ aliran ini menghasilkan tulisan-tulisan Gnostik yang banyak menganggu kekeristenan, terutama berkenaan dengan kitab-kitab Perjanjian Baru. Salah satu tokoh penting dalam ajaran Gnostik ini adalah "Valentius." Sebagaimana asal usul istilah Gnostikisme berasal dari bahasa Gerika "Gnosis" yang mempunyai arti "Pengetahuan", demikianlah poros ajarannya yang bertumpu pada pencarian rahasia pengetahuan. ${ }^{25}$ Dua pokok dasar ajaran Gnostik adalah: pertama, antikosmis yang radikal dengan menganggap bahwa semua yang bersifat materi atau kebendaan adalah "jahat"; kedua pandangan tentang penyamaan hal-hal yang spiritual dengan pengetahuan, khususnya pengetahuan tentang rahasia keselamatan. ${ }^{26}$

Penyematan istilah Injil-injil bagi judul traktat-traktat Nag Hammadi itu mencerminkan isinya, yang secara umum memang banyak membahas tentang diri Yesus Kristus. Kesimpulan tentang ajaran-ajaran umum dalam Injil-injil Gnostik akan dibahas pada bagian selanjutnya.

Tertampik oleh Terwujudnya Kitab-kitab Perjanjian Baru

Cukup lama kitab-kitab Perjanjian Baru - bahkan hingga sekarang - diterima sebagai yang berwibawa oleh gereja Kristen pada umumnya. Paling tidak ini menjadi

${ }^{19}$ Craig Bartholomew, Hahn Craig, Party Scott Robin and Christoper Sietz, Canon and Biblical Interpretation (Volume 7), 412.

${ }^{20}$ William "The Neo Gnostic: Alternatif Christianity of Elaine Pagels", Touchstone: A Journal of Mere Christianity," 34.

${ }^{21}$ Ibid, 120.

${ }^{22}$ George, "Gnostic Liberalisme", First Thing: A Montly Journal of Religion and Public, 26.

${ }_{23}^{23}$ Robinson, The Nag Hammadi Library, 2.

${ }^{24}$ Lane, Runtut Pijar (Sejarah Pemikiran Kristiani, 3.

${ }^{25}$ Jon Mister R. Damanik, "Pengaruh Ajaran Gnostik dalam Kekristenan Ditinjau dari Sejarah Gereja." Jurnal Teologi - Logon Zoes: Volume 2, No 1. (2018): 17.

${ }^{26}$ J. ED. Komoszewski, M. James. Sawyer, dan Daniel B. Wallace, Reinventing Jesus: Bagaimana Para Pemikir Skeptis Keliru Memahami Yesus dan Menyesatkan Budaya Populer (Jakarta: Perkantas - Divisi Literatur, 2011), 193. 
dasar atau tesis kokoh, bahwa seharusnya bukan kewibawaan kitab-kitab Perjanjian Baru yang perlu dibuktikan, melainkan segala keraguan dan kepalsuan yang merongrong Perjanjian Baru itu yang harus diuji dan ditampiknya. Demikian halnya sikap terhadap Injil-injil Gnostik. Penolakan terhadap otoritas dan kemungkinan masuknya Injil-injil Gnostik dalam kanon, terbukti paling tidak - pertama-tama oleh beberapa argumentasi berkenaan dengan kesahihan kanon Perjanjian Baru itu sendiri.

\section{Alasan Gap Waktu terhadap Kitab-kitab Kanonik Perjanjian Baru}

Historitas terwujudnya kitab-kitab Perjanjian Baru (kanonisasi) hingga menjadi satu kesatuan, merupakan salah satu patokan untuk menilai layak tidaknya Injil-injil Gnostik sebagai bagian dari kanon Perjanjian Baru. Selain tentu alasan dasarnya berkenaan dengan masalah kesesuai ajaran-ajarannya dengan Injil-injil kanonik, yang akan diungkap pada bahasan selanjutnya. Perihal diskusi panjang tentang waktu penulisan kitab-kitab Perjanjian Baru, hingga abad kesembilan belas oleh para ahli naskah-naskah Perjanjian Baru masih berkecenderungan menetapkan tanggal penulisan Perjanjian Baru yang mengarah ke abad kedua. ${ }^{27}$ Namun kemudian hari - memasuki akhir abad keduapuluh - muncul banyak pendapat yang meyakinkan bahwa semua Injil dan surat Perjanjian Baru berasal dari abad pertama. ${ }^{28}$ Seorang ahli Perjanjian Baru yang cukup tersohor yakni J.A.T Robinson, mengungkapkan gagasan tentang penanggalan ulang kitab-kitab Perjanjian Baru melalui bukunya yang berjudul Redating The New Testament. Dalam bukunya tersebut, beliau memberikan kesimpulan bahwa kitab-kitab Perjanjian Baru ditulis sebelum tahun 70 M. Menurut Jakob Van Bruggen, pendapatnya itu tidak banyak menimbulkan protes. ${ }^{29}$ Bagi Henry C Thiessen pandangan yang mengatakan bahwa kitab-kitab Perjanjian Baru ditulis pada abad kedua merupakan pandangan yang sudah usang. ${ }^{30}$

Berdasarkan rangkuman gagasan tentang tahap-tahap perwujudan kanon Perjanjian Baru oleh para ahli yang dideskripsikan oleh Jakob Van Bruggen - walau dirinya tidak terlalu menyetujui sepenuhnya - cukup umum bahwa para ahli Perjanjian Baru mengklasifikasikan sejarah tahap perkembangan perwujudan Perjanjian Baru ke dalam tiga tahap, yakni: periode pertama sebagai periode yang meliputi abad pertama terutama setelah tahun 50-an masehi sebagai masa dimana surat-surat Paulus sebagaian besar telah dikumpulkan dan Injil-injil kanonik (sebagaimana yang ada dalam Perjanjian Baru sekarang) sudah beredar luas, namun kanon Perjanjian Baru diyakini belum terbentuk. ${ }^{31}$ Para Rasul sebagai saksi Firman yang hidup - yaitu Tuhan Yesus - mulai menuangkan kesaksian-kesaksiannya dalam bentuk tulisan-tulisannya sebagaimana Perjanjian Lama, sembari terus memberitakan Injil dan memenangkan banyak jiwa. Pembentukan jemaat-jemaat di berbagai tempat telah ikut menyiapkan konteks universal guna menyambut dan menjaga otoritas kitab-kitab Perjanjian Baru yang

\footnotetext{
27 Michel J. Kruger, The Quest of Canon (Challanging The Status Quo In The New Testament Debat) (Apollos: Inter-Varsity Press, 2013), 156.

28 Jakon Van Bruggen, Siapa yang Membuat Akitab? (Penyelesaian dan Kewibawaan Perjanjian Lama dan Perjanjian Baru. (Surabaya: Momentum Christian Literatur. 2002), 29.

${ }^{29}$ Ibid, 29-30.

${ }^{30}$ Henry C. Thiessen, Teologi Sistematika (Malang: Penerbit Gandum Mas. 1992), 93.

${ }^{31}$ Bruggen, Siapa yang Membuat Akitab?, 30-31.
} 
belum terkanon. Tak pelak, bahwa gereja mula-mula memberikan penghargaan kitabkitab yang akan masuk dalam kanon Perjanjian Baru seperti Perjanjian Lama, walau otoritas Perjanjian Lama masih dominan. Penghargaan dan pentradisian berita-berita dari para rasul itu merupakan akibat normal dan sehat oleh karena kesahihan dan kekuatan inspirasi beritanya tentang kehidupan dan karya Tuhan Yesus. ${ }^{32}$ Periode kedua yang meliputi abad kedua adalah masa dimana tantangan bidat Marcion muncul. Yang mana bidat ini dianggap menjadi pemicu usaha pendataan, pengumpulan dan penyusunan kitab-kitab Perjanjian Baru. Pokok dasar bidat ini menolak keberadaan Perjanjian Lama, oleh karena karakter Tuhan Allah yang sangat berbeda dengan Perjanjian Baru. Perjanjian Lama bukanlah wahyu dari Tuhan Allah yang baik. ${ }^{33}$ Menurut Bruggen, anggapan demikian tidak harus diterima sepenuhnya. Selanjutnya sampailah periode ketiga adalah periode penyempurnaan mutlak atas kanon, khususnya Perjanjian Baru. Periode ketiga ini dipandang meliputi abad ketiga hingga abad keempat.

Rekonstruksi konklusif tentang perkembangan perwujudan kanon Perjanjian Baru sebagaimana di atas cukup berbeda dengan rekonstruksi perkembangan naskah dan kanon Pernjian Baru menurut Milton Fisher. Fisher membagi tahapan-tahapan pembentukan kanon Perjanjian Baru secara berturut-turut: 1) Abad pertama, adalah masa dimana kitab-kitab ditulis dan sekaligus dikopi untuk dibagikan kepada jemaatjemaat, 2) Abad kedua sebagai masa dimana tulisan-tulisan itu mulai disebarluarkan dan dibacakan berulang-ulang dalam komunitas sebagai tulisan-tulisa berotoritas, 3) Akhir abad ketiga kitab-kitab Perjanjian Baru mulai dihargai dan ditaruh sebagai Kitab Suci yang setara dengan Perjanjian Lama, 4) Lalu pada abad keempat dan kelima bapa-bapa gereja memberikan konklusi tegas masalah pengakuan kanon Perjanjian Baru. ${ }^{34}$ Menurut Jakob Van Bruggen, konstruksi historis dari tahap-tahap perwujudan kanon Perjanjian Baru secara demikian tidaklah sepenuhnya benar. Rekonstruksi itu hanya berdasarkan fragmentasi-fragmentasi dari abad-abad awal yang kurang lengkap. ${ }^{35}$ Menurut para ahli Perjanjian Baru, perkembangan pemberitaan Injil secara verbal dan kemudian munculnya injil-injil tertulis abad pertama hingga abad kedua tidak gampang direkonstruksi. Menurut Komoszewski, para rasul dan pemimpin gereja mula-mula yang masih muda sangat sibuk dengan pewartaan Injil. Beliau mengatakan:

Pada saat itu belum dirasakan perlu memiliki Injil tertulis. Penyebaran Kabar Baik tentang Yesus melaju dengan kecepatan yang mengagumkan sampai ke seluruh kekaisaran Romawi hanya dalam beberapa tahun pertama sejak lahirnya gereja. Ini merupakan kesaksian tentang keberhasilan para rasul dalam tugas pewartaan Injil secara lisan. ${ }^{36}$

\footnotetext{
${ }^{32}$ D.A. Carson dan John D. Woodbridge, Scripture and Truth. (Leicester: Inter-Varsity Press, 1983), 207.

${ }^{33}$ Bruggen, Siapa yang Membuat Akitab?, 50.

${ }^{34}$ Philip Wesley Comfort, The Origin of The Bible (Illinois: Tyndale House Publishers. 1998), 192.

${ }^{35}$ Bruggen, Siapa yang Membuat Akitab?, 32.

${ }^{36}$ J. ED. Komoszewski, M. James. Sawyer, dan Daniel B. Wallace, Reinventing Jesus: Bagaimana Para Pemikir Skeptis Keliru Memahami Yesus dan Menyesatkan Budaya Populer, 31.
} 
Antara kesibukan pemberitaan kabar baik tentang hidup Yesus Kristus dengan kesempatan penulisan kabar baik bagi kepentingan pembinaan jemaat-jemaat, sulit untuk digambarkan dengan tegas bagaimana mengidentifikasikan komposisi historisnya. Namun demikian, amatlah penting melihat penggambaran tentang rekonstruksi sejarah perkembangan terwujud dan tersatukannya kitab-kitab Perjanjian Baru tersebut dalam kepentingan melihat korelasi waktu dengan saat permunsulan Injil-injil Gnostik juga di sekitar abad kedua. Walaupun akan terdeskripsikan lebih jelas pandangan dan respon penolakan atas injil-injil lancung tersebut pada bagian-bagian selanjutnya, namun pada dasar penampikan secara alamiah bisa terdeteksi dari gap waktu permunculannya.

Dari celah-celah rekontruksi perwujudan kitab-kitab kanonik Perjanjian Baru di atas, Jakob Van Bruggen menyatakan bahwa munculnya bidat Marcion pada pertengahan abad kedua yang menyusun "Alkitab Kristiani” secara berat sebelah oleh karena hanya menerima Injil Lukas dan sepuluh surat Paulus, justru menjadi dasar kuat untuk mendapatkan kepastian bahwa seluruh kitab Perjanjian Baru harus sudah ada antara akhir abad pertama hingga pertengahan abad dua. Dengan tegas beliau menyatakannya, - melalui pertanyaan retorika - bahwa; "Bagaimana orang dapat menuduh Marcion sebagai perusak, kalau belum ada satu obyekpun yang dapat dirusak?". 37 Dari ungkapan tersebut, artinya secara tersirat harus diterima bahwa kanon Perjanjian Baru pasti sudah lengkap, sebelum perusak yang memotong-motong kanon Perjanjian Baru itu beraksi. Gambaran kuat tentang masa terbentuknya kanon Perjanjian Baru yang jauh lebih dahulu dari Injil-injil Gnostik ini menjadi salah satu argumentasi penolakan terhadap Injil-injil Gnostik. ${ }^{38}$ Jadi tidak mungkin Injil-injil Gnostik bisa diterima - atau dipaksakan sebagai yang harus masuk kanon Perjanjian Baru - padahal muncul dalam gap waktu yang signifikan, yakni limapuluh tahunan setelah kanon Perjanjian Baru ada. Argumentasi ini akan didukung oleh argumentasi-argumentasi selanjutnya.

\section{Alasan Terjaga dan Terbukanya Ajaran-ajaran Perjanjian Baru}

Menurut Komoszewski, Sawyer, dan Wallace dalam bukunya Reinventing Jesus masa antara kehidupan Tuhan Yesus hingga Injil-injil tertulis merupakan masa yang tidak sepi dari kegiatan. Pada masa itu para rasul dan saksi mata lainnya bersemangat mewartakan kabar baik dimana-mana. ${ }^{39}$ Pemberitaan-pemberitaan lisannya sangat penting dan disambut oleh jemaat-jemaat, yang kemudian menjadi tradisi lisan. Hal ini dikuatkan oleh fragmen-fragmen tulisan Papias dari Hierapolis. ${ }^{40}$ Secara khusus, walaupun fragmen-fragmen karya Papias hilang, namun masih ada sedikit fragmen darinya yang penting disimpan oleh Eusibius, yang memberikan informasi tentang pengenalan Papias akan tradisi-tradisi lisan tentang Injil dari para penatua yang hidup

\footnotetext{
${ }^{37}$ Bruggen, Siapa yang Membuat Akitab?, 31.

${ }^{38}$ Craig Bartholomew, Hahn Craig, Party Scott Robin and Christoper Sietz, Canon and Biblical Interpretation (Volume 7), 120.

${ }^{39}$ Gelora para rasul dan sambutan jemaat-jemaat baru dimana-mana, menyiapkan penjagaan atas ajaran-ajaran yang tak mungkin diselewengkan dan siap menolak penyelewengan. J. ED. Komoszewski, M. James. Sawyer, dan Daniel B. Wallace, Reinventing Jesus: Bagaimana Para Pemikir Skeptis Keliru Memahami Yesus dan Menyesatkan Budaya Populer, 34-35.

${ }^{40}$ Kruger, The Quest of Canon, 105.
} 
sebagai bapa apostolik. ${ }^{41}$ Lukas sendiri melalui Kitab Kisah Para rasul menggambarkan situasi tersebut. Dari Yudea, Samaria, hingga ke ujung-ujung bumi saat itu, Injil yang adalah kabar baik menjadi sangat diresponi dan segera menghasilkan komunitaskomunitas baru yang bernama jemaat sebagaimana Tuhan Yesus nyatakan dalam Matius 16:18. Jemaat-jemaat yang berdiri sebagai komunitas penerima berita Injil dan penjaga berita itu bisa meliputi jemaat rumah-tangga (Roma 16:5; I Korintus 16:19; Kolose 4:15), semua orang percaya dalam sebuah kota (Kisah Para Rasul 5:11; 8:1-3; 11:22; 12:1; I Korintus 15:9); keberadaan orang-orang percaya yang berada pada lingkup geografis tertentu (Kisah Para Rasul 9:31; Roma 16:1; I Korintus 16:19). Kisah hidup dan ucapan-ucapan Yesus yang disampaikan ratusan atau bahkan ribuan kali oleh para rasul dan saksi mata, tentunya terjaga dan mengiang dalam kehidupan jemaat yang sedemikian tersebur luas. ${ }^{42}$ Pewartaan secara lisan yang sedemikian terbuka dan meluas pada masa itu, memberikan implikasi yang sangat penting bagi proses terwujudnya kanon Perjanjian Baru dikemudian hari. Lagi Komoszewski menyatakan bahwa penyerbaran kabar baik secara cepat, meluas, dan terbuka, menjadi jaminan bahwa apabila dikemudian hari ada pengubahan berita melalui tulisan-tulisan dari para rasul, maka generasi awal dan komunitas jemaat akan mengetahui dan menyampaikan keberatan-keberatannya. ${ }^{43}$ Apalagi kemudian Injil-injil yang tertulis dikopi dan disebarluaskan di antara jemaat-jemaat yang telah terbentuk sejak hari Pentakosta (Kisah Para Rasul 2). ${ }^{44}$

Ahli-ahli Perjanjian Baru seperti Daniel B Wallace, Michael Licona, M. James Sawyer mengungkapkan betapa berlimpahruahnya manuskrip-manuskrip Perjanjian Baru dari abad kedua sampai keempat yang mengkonfirmasi keberadaan kitab-kitab Perjanjian Baru yang selesai pada pertengahan abad kedua. Jumlah manuskrip Yunani saja bisa mencapai 5800 naskah. Belum lagi naskah-naskah dalam bahasa lain yang mencapai puluhan ribu. ${ }^{45}$ Jadi tak pelak lagi kekuatan tersebarluasnya Injil secara lisan dan terbuka tentang Yesus Kristus dalam ratusan bahkan ribuan kali, komitmen penghargaan jemaat-jemaat generasi pertama, dan tentunya tulisan-tulisan Injil terkopi dan tersebar luas telah menjadi perisai kokoh yang siap menampik kesesatan dan ajaranajaran palsu di kemudian hari. ${ }^{46}$ Kendatipun masa-masa tersebut kitab-kitab Perjanjian Baru belum berbentuk "satu ikatan secara fisik" (baca: satu bendel) namun pengakuan kitab-kitab yang memang inspirasi Ilahi - khususnya Perjanjian Baru - pada abad pertama sudah selesai. Dengan demikian secara logis dapat disimpulkan bahwa kanonisasi lebih merupakan pengakuan terhadap kitab-kitab, oleh karena tuntutan kitabkitab itu sendiri, bukan oleh wewenang gereja atau konsili. Karena kitab-kitab itu

\footnotetext{
${ }^{41}$ Bruggen, Siapa yang Membuat Akitab?, 45-46.

42 Komoszewski, M. James. Sawyer, dan Daniel B. Wallace, Reinventing Jesus: Bagaimana Para Pemikir Skeptis Keliru Memahami Yesus dan Menyesatkan Budaya Populer, 34-35.

${ }^{43}$ Ibid, 35.

${ }^{44}$ Philip Wesley Comfort, The Origin of The Bible, (Illinois: Tyndale House Publishers. 1998), 68.

45 Komoszewski, M. James. Sawyer, dan Daniel B. Wallace, Reinventing Jesus: Bagaimana Para Pemikir Skeptis Keliru Memahami Yesus dan Menyesatkan Budaya Populer, 86-95.

${ }^{46}$ Cars on dan John D. Woodbridge, Scripture and Truth, 49.
} 
memang inspirasi Roh Allah kepada para rasul-Nya, maka dari dalamlah otoritas itu muncul dan mengikat. ${ }^{47}$

Karakteristik ajaran dan penyebaran kitab-kitab kanonik Perjanjian Baru yang bersifat terbuka, luas, berkesinambungan, dan banyak kopian sebagaimana terungkap di atas, sangat bertentangan dengan ajaran dan tersebarnya Injil-injil Gnostik. Injil-injil Gnostik merupakan ajaran-ajaran yang diterima dan diajarkan secara rahasia. ${ }^{48}$ Ajaranajarannya bersifat tertutup, mistik dan sinkristik. ${ }^{49}$ Bahkan penyebarannyapun sangat terbatas dan sangat kurang pengakuan dalam gereja purba. ${ }^{50}$ Perbedaan yang sedemikian menyolok dalam penerimaan dan penyebarannya, memberikan penguatan argumentasi, bahwa Injil-injil Gnostik adalah Injil-injil palsu yang tidak layak masuk kanon. Tepatlah pendapat Bartholomeus, bahwa tradisi dan kesetiaan orang-orang percaya pada tulisan-tulisan kanonik Perjanjian Baru menyiapkan benteng untuk menangkal ancaman ajaran-ajarang Gnostik yang mewarnai Injil-injil Gnostik. ${ }^{51}$

\section{Alasan Kekontrasan Ajaran Injil-injil Gnostik dengan Kitab-kitab Kanonik}

Menurut Rodolphe Kasser dan rekan-rekan penelitiannya, gerakan keagamaan Gnostik dipandang sebagai gerakan keagamaan yang memiliki banyak variasi aliran. Mereka saling berbeda satu dengan yang lainnya. ${ }^{52}$ Namun meski banyak variasi ajaran yang non-esensial, umumnya aliran-aliran dari gerakan gnostisisme sepaham dalam memandang dunia ini. Dunia ini bagi mereka bukanlah merupakan rumah abadi bagi manusia. Dunia ini pada dasarnya adalah jahat. Di dalamnya penuh dengan penderitaan dan jerat kehidupan manusia serta makhluk-makhluk lainnya. Manusia bukan berasal dari dunia materi ini. ${ }^{53}$ Ia berasal dari percikan Ilahi yang disebut aeon. Oleh karena suatu bencanalah, maka manusia telah terperangkap dalam tubuh ragawi yang jahat dan fana ini. Permulaaan segala sesuatu adalah alam ilahi, dimana ada Allah dengan para aeon-nya (baca: api percikan-percikan ilahi). Bencana kosmik telah menjerat aoen itu. Tragedi terjeratnya aeon itulah yang menjadi asal-muasal terbentuknya makhlukmakhluk di luar alam Ilahi, secara khusus manusia. ${ }^{54}$

Menurut pemahaman umum dari ajaran Gnostik, manusia dan makhluk yang telah terjerat (baca: terkurung) oleh materi yakni darah dan daging masih bisa terbebas dari kurungan daging dan kembali ke alam ilahi hanya melalui pencarian rahasia pengetahuan. $^{55}$ Terjadinya manusia dan kembalinya manusia secara demikian, tentu berbeda sekali dengan ajaran Alkitab. Seluruh Perjanjian Baru dengan jelas

\footnotetext{
${ }^{47}$ Thiessen, Teologi Sistematika, 92.

${ }^{48}$ F. F. Bruce, The Canon of Scripture (Glasgow: Chapter House Ltd, 1988), 93.

${ }_{50}^{49}$ Robinson, The Nag Hammadi Library, 9.

50 Komoszewski, M. James. Sawyer, dan Daniel B. Wallace, Reinventing Jesus: Bagaimana Para Pemikir Skeptis Keliru Memahami Yesus dan Menyesatkan Budaya Populer, 192.

51 Craig Bartholomew, Hahn Craig, Party Scott Robin and Christoper Sietz, Canon and Biblical Interpretation (Volume 7), 120.

${ }^{52}$ Rodolphe Kasser, Marvin Meyer, dan Gregor Worst, Injil Yudas, (Jakarta: Gramedia Pustaka Utama, 2006), 84.

53 Setiawan, Roby. "Tanggapan Terhadap Gnosticism dan Injil Tomas." Jurnal Teologi dan Pendidikan Agama Kristen. Volume 2, No. 1 (2015): 2-3.

${ }^{54}$ Kasser, Marvin Meyer, dan Gregor Worst, Injil Yudas, 84-86.

${ }^{55}$ Ibid, 87.
} 
mengajarkan bahwa keselamatan hanya bisa terjadi melalui iman kepada pengorbanan Tuhan Yesus Kristus. Ajaran itu eksplisit, terbuka, dan tegas. ${ }^{56}$

Selain pengajaran dasar tentang manusia yang kontradiksi dengan ajaran orthodoks, tentu patut mencermati ajaran-ajaran Gnostik tentang kehidupan Tuhan Yesus. Gambaran kehidupan Tuhan Yesus dalam Injil-injil Gnostik lebih banyak menonjolkan aspek keilahiannya. Kemanusiaan Yesus Kristus hanyalah sekedar "nampak" seolah-olah seperti manusia, padahal substansinya bukan tubuh (darah dan daging). Dia adalah roh yang membawa rahasia pengetahuan agar manusia bisa kembali ke asal-usulnya. Para penulisnya memandang bahwa mereka mendapatkan pengajaran-pengajaran yang bersifat rahasia dan mistik secara langsung dari Tuhan Yesus. Dalam pemikiran gnostik, pengetahuan ini tidak dimiliki oleh semua orang. Gnosis merupakan semacam pengetahuan rahasia yang hanya dimiliki oleh anggotaanggota kelompok itu. ${ }^{57}$ Pengetahuan inilah yang membawa pembebasan jiwa dan kembali kepada yang ilahi.

Bagi penganut Gnostik yang sekaligus menganut Kristen, Kristus sendiri dipandang sebagai aeon (dewata) dari alam Ilahi - yang dilahirkan ke dalam dunia wujud daging dan darahnya dianggap tidak sejati. Menurut De Jong, ajaran Gnostik meletakkan Yesus ini sebagai yang memiliki peran dalam proses pengungkapan rahasia gnosis bukan tindakan penyelamatan melalui kematian dan kebangkitan-Nya. ${ }^{58}$ Kemanusiaan Yesus Kristus hanya sekedar nampak seolah-olah seperti itu. Kendatipun tidak semua aliran Gnostik sepakat seperti itu.

Yang pasti, umumnya penganut Gnostik dan yang sekaligus penganut Kristen meyakini bahwa Dia adalah roh yang membawa rahasia pengetahuan, agar manusia bisa kembali ke asal-usulnya. Pencapaian keselamatan manusia terletak pada usaha mempelajari dan menemukan rahasia pengetahuan yang dari Yesus Kristus. Oleh pengetahuan yang akan dicapainyalah manusia mengalami kehidupan lepas dari penderitaan. Dengan kata lain, bahwa dirinya beroleh keselamatan atau kembali ke surga harus dengan cara banyak belajar rahasia pengetahuan dari Yesus Kristus. Menurut orang-orang Gnostik yang kemudian memeluk kekristenan - yakni kemungkinan sekali orang-orang yang ada di balik terwujudnya Injil-injil Gnostik Yesus Kristus dipandang sebagai yang telah menyampaikan rahasia-rahasia pengetahuan kepada murid-murid terdekat dan setia. ${ }^{59}$ Kendatipun pendapat ini kontradiksi dengan historis dalam Injil-injil sinoptik bahwa Thomas dan Yudas sebagai contoh "penulis" Injil Tomas dan Yudas bukanlah orang-orang setia. Pengetahuan yang disampaikan Yesus secara rahasia itu juga menyangkut pengetahuan akan diri manusia yang termasuk di dalamnya adalah mengenai asal usul, bagaimana manusia bisa sampai ke dunia ini, dan bagaimana manusia bisa kembali ke alam surgawi.

\footnotetext{
${ }^{56}$ Yohanes 3:16; Kisah Para Rasul 4:12; Efesus 2:8,9 dan banyak lag referensi yang lain.

57 Matheus Purwatma. "Tantangan Gnostik bagi Hidup Beriman Masa Kini." Jurnal Orientasi Baru Volume 2, No. 2. (2012): 192.

58 Maksudnya bahwa keselamatan tidak bertumpu pada karya kematian dan kebangkitan-Nya, namun melalui rahasia-rahasia yang diungkap-Nya kepada para pengikut-nya. De Jong, Kees, "The Resurection of the Gnostic: The Gospel of Judas, Da Vinci Code, A Historical Review of Religion," Gema: Jurnal Teologi, (2007): 7.

${ }^{59}$ Michael J Wilkins and J.P. Moreland, Jesus Under Fire: Modern Scholarship Reinverts the Historical Jesus, (Michigan: Zondervan Publishing House, 1995), 23.
} 
Cukup banyak orang Kristen pada masa itu terpesona dan akhirnya menjadi penganut faham Gnostik. Bahkan mereka pemandang bahwa ajaran Gnostik mengungkapkan misteri penundaaan kedatangan Yesus Kristus kedua kalinya. ${ }^{60}$ Dan sebaliknya, ada banyak penganut Gnostik yang sekaligus orang Kristen. Bagi mereka, Kristuslah yang diyakini telah membawa pengetahuan rahasia itu dari atas. Sebagaimana penulis telah mengungkapkan kutipan di atas, bahwa Dia dipercaya sebagai yang mewahyukan kebenaran itu secara rahasia kepada pengikut-pengikut terdekat-Nya. Sebagai contoh, dalam pembukaan Injil Yudas yang belakangan populer sebagai salah satu injil Gnostik, ${ }^{61}$ diberitahukan bahwa apa yang dipaparkan di dalamnya merupakan kisah rahasia mengenai pewahyuan yang diucapkan oleh Yesus dalam pembicaraan-Nya dengan Yudas Iskariot. ${ }^{62}$ Pendeknya, kekristenan Gnostik memahami Yesus Kristus sebagai yang pemegang kunci rahasia pengetahuan untuk manusia bisa kembali ke surga, yang hanya dirahasiakan bagi murid-murid tertentu saja.

Ajaran-ajaran mendasar tentang dunia materi yang jahat, keberasalan manusia yang adalah aeon terjerat darah dan daging, serta tentang Tuhan Yesus yang bukan manusia sejati namun sumber pewahyuan rahasia-rahasia pengetahuan untuk keselamatan yang dituturkan dalam Injil-injil Gnostik, meneguhkan alasan penampikan Injil-injil Gnostik untuk masuk dalam kasatuan kanonik Perjanjian Baru. Sebagaimana disimpulkan oleh Martin McNamara, bahwa ajaran-ajaran Gnostik adalah sebauah agama yang memberontak dan pemikiran kreatif yang secara sistematis pekerjaanpekerjaannya dihancurkan oleh Kristen orthodoks di antara abad kedua hingga keenam. ${ }^{63}$ Ajaran-ajarannya Itulah poros ajaran-ajaran dari gerakan Kristen Gnostisisme yang tertuang dalam Injil-injil Gnostiknya. ${ }^{64}$

Tertampik oleh Tokoh-tokoh Penting Abad Kedua hingga Ketiga

Menurut Yakob Van Bruggen abad ketiga merupakan abad penuh pergumulan bukan menyangkut persoalan pengakuan kitab-kitab kanonik Perjanjian Baru - tetapi lebih pada persoalan keraguan dan gugatan-gugatan menyangkut para penulis, serta munculnya naskah-nagkah sesat yang pura-pura kuno. ${ }^{65}$ Berberapa tokoh berikut patut terus menjadi perhatian dalam hal sikap-sikap peneguhannya terhadap kitab-kitab kanonik Perjanjian Baru di satu sisi. Di sisi lain, sikap tegas meraka terhadap Injil-injil paslu atau naskah-naskah palsu.

\section{Irenaeus}

Seorang presbiter muda yang kemudian menjadi uskup di Lyon pada tahun 177, sangat gencar melawan bidat-bidat pada zamannya. Di satu sisi ia menunjukan pembelaan yang teguh terhadap kekristenan rasuli dan kitab-kitab Perjanjian Baru. Di sisi lain

\footnotetext{
${ }^{60}$ Miguel Vatter, "Political Theology," Jurnal Theology, Volume 20, Is sue 6 (September 2019): 474.

${ }^{61}$ Kasser, Marvin Meyer, dan Gregor Worst, Injil Yudas, (Jakarta: Gramedia Pustaka Utama, 2006), 8484.

${ }^{62}$ Ibid, 100-101.

63 Martin McNamara, "The Secret Book of John the Gnostic Gospel," Heythrop Journal, (Maret 2012): 296-297.

${ }^{64}$ Kasser, Marvin Meyer, dan Gregor Worst, Injil Yudas, (Jakarta: Gramedia Pustaka Utama, 2006), 8486.

${ }^{65}$ Bruggen, Siapa yang Membuat Akitab?, 67.
} 
beliau juga bertindak aktif menentang keras ajaran-ajaran sesat. ${ }^{66}$ Melalui pembuktian dan argumentasinya yang kuat, ia berusaha menentang kesesatan-kesesatan, terutama gerakan Gnostikisme. Ia menyangkal dengan tegas tentang sikap para penganut Kristen Gnostik yang menganggap dirinya penjaga tradisi-tradisi rahasia dari para rasul untuk diteruskan secara rahasia pula. Hal demikian - menurut Ireneaus - sangat mustahil, mengingat keterbukaan dan keluasaan kesinambungan ajaran para rasul. ${ }^{67}$ Sekitar tahun 180 Irenaeus mengutuk Injil Yudas dengan keras. ${ }^{68}$

\section{Tertullianus}

Bapak Teologi Latin yang lahir sekitar tahun 160 di Katargo ini telah panjang lebar melawan bidat Marcion melalui karyanya berjudul Adversus Marcionem. Dalam buku terebut beliau menggambarkan Marcion sebagai "tikus yang menggerogoti" kanon Perjanjian Baru. ${ }^{69}$ Bersama dengan Irenaeus, ia juga menulis karya-karya dogmatis melawan ajaran sesat lain, secara khusus ajaran-ajaran Gnostik. Ketangguhannya dalam melawan aliran-aliran Gnostikisme dipandang luar biasa oleh tokoh-tokoh sezamannya. $^{70}$ Dia menolak keras hak penganut-penganut Injil-injil paslu tersebut sebagai yang juga berhak menggunakan Alkitab. ${ }^{71}$ Oleh Tertullian, pengakuan kitab suci Kristen sebagai Perjanjian Baru, yakni kitab-kitab kanonik sebagaimana adanya sekarang. Dengan demikian mengakui kesetaraan kitab-kitab kanonik Perjanjian Baru sebagai setara dengan kitab suci orang Yahudi yakni Tanakh. ${ }^{72}$ Hal ini juga yang menjadi bukti penguat betapa dininya kesahihan dan kemuliaan kitab-kitab kanonik Perjanjian Baru. Seluruh pelayanannya dicurahkan untuk membuktikan imannya pada ajaran-ajaran rasuli dan kitab-kitab Perjanjian Baru yang adalah konsisten. Sementara lawan-lawannya dipandangnya sebagai yang tidak konsisten. ${ }^{73}$

\section{Clemens dari Aleksandria}

Clemens dari Aleksandria yang bernama lengkap Titus Flavius Clemens dilahirkan dari keluarga kafir Yunani pada pertengahan abad kedua. Kehidupannya di Aleksandria telah memungkinkan dirinya berkenalan dengan Gnostikisme, yang mana memang pada abad kedua Mesir menjadi sarang bagi ajaran Gnostikisme. Penganiayaan yang dialami Clemens telah membuatnya meninggalkan Aleksandria menuju Asia Kecil. Pada tahun 216, "Sang Orthodoks intelektual" itu meninggal dunia. ${ }^{74}$

Karya-karya Clemens cukup penting bagi pengajaran Kristen. Tiga karyanya terkenal adalah nasihat kepada orang Yunani (suatu tulisan apologet), pendidikan bagi yang baru masuk Kristen, dan serba-serbi (stromateis) yang membahasa tentang tahapan

\footnotetext{
${ }^{66}$ Lane, Runtut Pijar (Sejarah Pemikiran Kristiani), 9.

${ }^{67}$ Robert L. Reymond, A New Systematic Theology of The Christian Faith (Nashville: Thomas Nelson Publishers. 1999), 48.

68 James M. Robinson, The Nag Hammadi Library (San Fransisco: Harper \& Row Publishers. 1981), 52.

69 Ibid.

${ }^{70}$ Lane, Runtut Pijar (Sejarah Pemikiran Kristiani), 13.

${ }^{71}$ Comfort, The Origin of The Bible, 66.

72 Ibid. 67.

${ }^{73}$ Lane, Runtut Pijar (Sejarah Pemikiran Kristiani), 13.

74 Begitu kuatnya ingin membawa iman tidak berhenti pada keyakinan afeksi atau hati, namun mampu memberikan penjelasan secara inteletual. Ibid, 14.
} 
iman menuju kepada pengetahuan. Kendatipun Clemens menerima hal-hal tertentu akan ajaran Gnostik, namun dirinya lebih banyak melawannya. Secara umum dia banyak keberatan dengan ajaran sesat Gnostikisme, dengan cara mencari tandingan bagi ajaran Gnostik. $^{75}$ Bersama Origen, Tertullians, Irenaesus banyak mengarahkan tulisanulisannya untuk melawan orang-orang yang tidak percaya dan kaum murtad dari iman Kristen, yang juga dikenakan kepada penganut aliran-aliran Gnosik. ${ }^{76}$ Sebagai seorang Kristen, dia memandang bahwa filsafat Yunani mempersiapkan orang Yunani bagi Kristus. Dia menerima "pengetahuan" sebagai tahap selanjutnya akan "iman."

\section{Origens}

Seperti sudah disinggung bersama Clemens di atas, Origens yang hidup antara tahun 185 -254 termasuk tokoh Kristen yang yang hebat. Ia menyusun suatu studi eksegetis dan tajam tentang Perjanjian Lama dan Perjanjian Baru. Karyanya menunjukkan kesungguhannya dalam pembelaan dan penghargaan atas Alkitab. ${ }^{77}$ Dia sangat menekankan inspirasi Allah dalam kitab-kitab kanonik. Dia sepaham dengan ajaran orthodoks tentang inspirasi kitab-kitab dalam Alkitab sebagaimana keyakinan gerejawi umumnya, walaupun dia mengikuti secara aktif perdebatan tentang kepastian penulis-penulis kitab tertentu, seperti perdebatan apakah benar 2 Petrus ditulis oleh Petrus, 2-3 Yohanes oleh Yohaned, Ibrani oleh Paulus. Namun demikian dalam perdebatan-perdebatan yang diikutinya, dirinya tetap menerima sepenuhnya bahwa perdebatan itu tidak mempermasalahkan statusnya dalam kanon Perjanjian Baru. ${ }^{78}$ Sama seperti Clemens dari Aleksandri, Origens giat menentang kitab-kitab yang tidak otentik kanonitasnya, seperti tulisan gembala Hermas, Tobit dan tulisan-tulisan Gnostik. $^{79}$

\section{Eusebius}

Eusbius adalah bisop dari Kaesaria sebelum tahun 315. Dia sejarawan gereja yang sangat mengagumi Origens. Dia dengan tegas telah menandai semua tulisan dan kitab-kitab apokrif atau tulisan-tulisan yang merusak kehidupan gereja orthodoks. ${ }^{80}$ Ketelitiannya dalam menjumpai tradisi-tradisi yang paling tua, telah membuatnya mampu menggambarkan priode para rasul dan para pemimpin yang menggantikan para rasul di berbagai pusat gerejawi. ${ }^{81}$ Dengan demikian dia sangat paham tentang kitabkitab yang dimuat dalam Perjanjian Baru dan yang sejak semula sudah dihormati oleh jemaat. Dia mampu memberikan gambaran kepastian jumlah kitab-kitab yang masuk dalam Perjanjian Baru. Dalam ulasannya tentang tiga pembagian kitab-kitab, yang terdiri dari: 1). Kitab-kitab yang tidak dipermaslahkan, 2). Kitab-kitab yang dipermasalahkan, dan 3). Kitab-kitab palsu, Eusebius meletakkan kitab-kitab kanonik Perjanjian Baru sebagai yang tidak dipermasalahkan kesatuaan jumlah dan

\footnotetext{
${ }^{75}$ Ibid, 15.

${ }^{76}$ Bruggen, Siapa yang Membuat Akitab?, 35.

${ }^{77}$ Comfort, The Origin of The Bible, 73.

${ }^{78}$ Perdebatan pukan masalah status masuk tidaknya kendalam kanon Perjanjian Baru, tetapi lebih kepada mendalami kepenulisan kitab-kitab terkanon. Bruggen, Siapa yang Membuat Akitab?, 59.

${ }^{79}$ Ibid, 164

${ }^{80}$ Comfort, The Origin of The Bible, 74.

${ }^{81}$ Bruggen, Siapa yang Membuat Akitab?, 59.
} 
kanonitasnya. Untuk kitab-kitab apokrif dan tulisan-tulisan Gnostik dikategorikan sebagai kitab-kitab palsu. Menurut Yakob Van Bruggen, pengelompokan yang dilakukan oleh Eusebius tersbut salah satunya bertujuan untuk menyerang kaum bidat atau orang-orang murtad yang berusaha melakukan pemalsuan-pemalsuan. ${ }^{82}$

Tinjauan to the point (baca: langsung menyentuh permasalahan) tentang pandangan tokoh-tokoh penting di atas terhadap Injil-injil Gnostik pada abad kedua bahkan hingga awal abad keempat tersebut, semakin menegaskan bahwa Injil-injil palsu tersebut layak dihindarkan sebagai dasar perdebatan apalagi dalam kepentingan mencurigai Injil-injil kanonik.

\section{Implikasi}

Pelajaran penting dari penelitian ini adalah tentunya semakin mengokohkan doktrin tentang kanon Perjanjian Baru yang selama ini dipegang oleh kaum Injili, melalui penambahan argumentasi lebih detil persoalan kanonisasi Alkitab.

Bagi umumnya orang-orang percaya, pemahaman ini membekali kesiapan menghadapi serangan dan tuduhan-tuduhan terhadap pemalsuan Alkitab. Orang-orang percaya tidak perlu ragu dan takut dengan segala temuan yang diduga akan menggoyahkan keyakinan imannya pada Alkitab yang adalah Firman Tuhan kokoh tak tergoncang.

\section{Rekomendari bagi Penelitian Lanjutan}

Penelitian ini masih perlu dilanjutkan, mengingat penelitian ini baru terfokus pada gambaran makro sikap dari aliran besar kekristenan yang sejarahnya berpegang kuat pada tradisi orthodoksi terhadap Alkitab dengan komunitas Gnostik yang relatif kecil namun memiliki produk tulisan-tulisan yang besar saat itu, yakni pengikutpengikut aliran Gnostik. Sebagaimana disebut di atas, bahwa mereka bisa termasuk orang-orang Kristen yang menganut Gnostik ataupun para penganut Gnostik yang masuk kristen pada abad kedua hingga ketiga. Topik-topik berikut bisa dipertimbangkan sebagai studi lanjutan dari penelitian ini, Pertama, bagaimana sikap komunitas Kristen Gnostik (baca: orang-orang Kristen yang sinkritistik dengan Gnostik) sendiri terhadap Alkitab sebanarnya saat itu? Kedua, apakah alasan-alasan mendasar yang menarik dan terasa relevan dari ajaran-ajaran aliran Gnostik bagi para pengikutnya saat itu? ketiga, bagaimana merumuskan apologetika bagi penentang-penentang Kristen yang masih memanfaatkan Injil-injil Gnostik dalam menggugat kekritenan sejati saat ini?

\section{Kesimpulan}

Berdasarkan hasil temuan tentang penelitian literatur di atas maka bisa disimpulkan, bahwa Injil-injil Gnostik layak tidak masuk dalam kitab-kitab kanonik Perjanjian Baru ,oleh karena gab waktu yang signifikan antara kitab-kitab kanonik Perjanjian Baru yang tertulis sekitar pertengahan abad pertama hingga awal abad kedua dengan terwujudnya Injil-injil Gnostik pada akhir abad kedua menuju pertengahan abad ketiga, menjadikan kemustahilan untuk mengakui keberadaannya sebagai asli dari para rasul dan teman-teman dekatnya. Sifat terbuka, meluas, dan tersambutnya Injil-injil

\footnotetext{
${ }^{82}$ Ibid, 171.
} 
kanonik Perjanjian Baru di tengah-tengah jemaat yang berkembang sedemikian pesat dan mendunia, juga menjadi dasar yang kuat untuk menolak Injil-injil Gnostik yang bersifat "rahasia, terbatas, dan tidak disambut luas" oleh jemaat-jemaat Kristen purba. Ajaran Injil-injil Gnostik yang kontradiksi - bahkan terlihat aneh - dibandingkan dengan ajaran Injil-injil kanonik Perjanjian Tentang kehidupan Tuhan Yesus dan jalan keselamatan manusia, membuat Injil-injil palsu sangat beralasan untuk ditampik menjadi bagian dari kanon.

Argumentasi terkait dari keempat di atas yang juga signifikan adalah pendapat dari bapa-bapa gereja purb. Alasan-alasan penolakan Injil-injil Gnostik pada abad kedua hingga ketiga, juga nampak jelas dari pandangan-pandangan langsung beberapa tokoh penting abad kedua hingga abad ketiga seperti Irenaeus, Tertullian, Clemens, Origens, dan Esuibius. Tokoh-tokoh yang tersebut menunjukkan ketegasannya dalam hal menolak keberadaan Injil-injil Gnostik.

\section{Rujukan}

Alkitab, Jakarta: Lembaga Alkitab Indonesia. 2008.

Bartholomew, Craig., Hahn, Scott., Party, Robin., and Seitz, Christoper. Canon and Biblical Interpretation (Volume 7). Grand Rapids: Redeemer University College. 2006.

Bruce FF, The Canon of Scripture. Glasgow: Chapter House Ltd, 1988.

Bruggen, Jakon Van. Siapa yang Membuat Akitab? (Penyelesaian dan

Kewibawaan Perjanjian Lama dan Perjanjian Baru. Surabaya: Momentum

Christian Literatur. 2002.

Cahana, Jonathan, "None of Them Knew Me of My Brothers: Gnostic

Antitraditionalisme and Gnosticism as Cultural Phenomenon", Journal of

Religion, Volume 94 (2013): 49-73.

Carson, DA., Woodbridge, John D. Scripture and Truth. Leicester: Inter-Varsity

Press. 1983.

Comfort, Philip Wesley. The Origin of The Bible. Illinois: Tyndale House Publishers. 1998.

Damanik, Jon Mister R. "Pengaruh Ajaran Gnostik dalam Kekristenan

Ditinjau dari Sejarah Gereja.” Jurnal Teologi-Logon Zoes: Volume 2, No 1. (2018) 2018. 15-23.

George, Robert P, "Gnostic Liberalisme", First Thing: A Montly Journal of Religion and Public (Desember 2016): 33-39.

Geisler, Norman dan Brooks, Ron, Ketika Alkitab Dipertanyakan, Yogyakarta: Andi Offset, 2006.

Kasser, Rodolphe, Marvin Meyer, dan Gregor Worst, Injil Yudas, Jakarta: PT Gramedia Pustaka Utama, 2006.

Kees, De Jong, "The Resurection of the Gnostic: The Gospel of Judas, Da Vinci Code, A Historical Review of Religion," Gema: Jurnal Teologi, (2007), 1-14

Komoszewski, J. ED., Sawyer, M. James., dan Wallace, Daniel B. Reinventing

Jesus: Bagaimana Para Pemikir Skeptis Keliru Memahami Yesus dan

Menyesatkan Budaya Populer. Jakarta: Perkantas - Divisi Literatur. 2011.

Kruger, Michel J. The Quest of Canon (Challanging The Status Quo In The

New Testament Debate. Apollos: An Imprint of Inter-Varsity Press. 2013.

Lane, Tony. Runtut Pijar (Sejarah Pemikiran Kristiani). Jakarta: BPK Gunung Mulia. 
1990.

McNamara, Martin, "The Secret Book of John the Gnostic Gospel," Heythrop Journal, (Maret 2012): 296-297.

Olsen, Andy, "Go West Young Scholar," Journal: Christian Today, Volume 63, Issue 7 (September 2019): 7-9.

Pate, C. Marvin dan Sheryl L, Disalibkan oleh Media. Yogyakarta: Andi Offset, 2007.

Purwanto, Lukman. "Perbandingan Ajaran Gnostik is me dengan Ajaran

Reformed Mengenai Pengetahuan Akan Allah." Jurnal Teologi dan

Pendidikan Agama Kristen. Volume 17, No 1. (2019): 43-63.

Purwatma, Matheus. "Tantangan Gnostik bagi Hidup Beriman Masa Kini." Jurnal Orientasi Baru Volume 2, No. 2. (2012): 189-200.

Reymond, Robert L. A New Systematic Theology of The Christian Faith. Nashville: Thomas Nelson Publishers. 1999.

Robinson, James M. The Nag Hammadi Library. San Fransisco: Harper \& Row Publishers. 1981.

Menafsir Ulang Peran Yudas (The Secrets of Judas). Jakarta Selatan: PT. Cahaya Insan Suci. 2006.

Setiawan, Roby. "Tanggapan Terhadap Gnosticism dan Injil Tomas." Jurnal Teologi dan Pendidikan Agama Kristen. Volume 2, No. 1 (2015): 1-10.

Subana, M., dan Sudrajat. Dasar-dasar Penelitian Ilmiah. Bandung: Penerbit Pustaka Setia. 2005.

Sugiono. Metode Penelitian (Kuantitatif, Kualitatif, dan R\&D). Bandung: Penerbit AlfaBeta, 2017.

Thiessen, Henry C. Teologi Sistematika. Malang: Penerbit Gandum Mas. 1992.

Wilkins, Michael J and Moreland, J.P. Jesus Under Fire: Modern Scholarship Reinverts the Historical Jesus. Grand Rapids, Michigan: Zondervan Publishing House, 1995.

William, J Tiche, "The Neo Gnostic: Alternatif Christianity of Elaine Pagels", Touchstone: A Journal of Mere Christianity," Volume 24, Issue 6, November/ December (2013): 34-49.

Vatter, Miguel, "Political Theology," Jurnal Theology, Volume 20, Issue 6 (September 2019): 472-487. 